\title{
Social Citizenship and Plural Values of Land: Land Acquisition Cases from India
}

\section{Sattwick Dey Biswas}

Institute of Public Policy, National Law School of India University, Bangalore, India

E-mail: sattwick.deybiswas@udo.edu

In the globalised economy, the value chains of production have crossed national boundaries. As a result, the demand has intensified for land acquisition in order to set up production facilities and infrastructure. This industrialisation proceeded rapidly, and, therefore, a vast area of land had to be acquired, both in the Global South and in the North. This development has led to many conflicts. These conflicts are the result of the inability to understand the plural values of land in the realisation of property rights in social citizenship. This article has considered two land expropriation case study areas in India, Salbani and Singur in West Bengal, as a source of empirical data. The empirical evidence suggests that the straitjacket of monorational property rights discourse, which heavily relies on the absolute ownership and control (via exclusion of others) ignores the different ways in which plural land values shape ideas of social citizenship. There is a need to rediscover the 'social' in citizenship to ensure the subordination of market price to the ideals of social justice.

Keywords: Social citizenship, social justice, plural values, market price and land acquisition.

\section{Introduction}

Going back to the record of the Constitutional Convention of the United States of America in 1787, one of the founding fathers, James Madison, was convinced that people would not tolerate an unacceptable level of inequality and would use their voting power to attack the minority of the opulent (Yates, 1787). This fear goes back to the Politics of Aristotle, who claimed that if one of these things (access to land or a non-impoverished life) remains distant for the majority, then the majority will use their democratic powers to rewrite public policy to initiate steps against the few who have all the pleasures of life (Barnes, 1991; original text 1304b: 20-1305a7). Madison embraced reduced democracy where the selected body of the 'Senate' initially had higher power and authority than the 'House of Representatives', whereas Aristotle argued for reducing inequality. The Madisonian state was eager to 'protect the minority opulent against the majority' poor (Yates, 1787). The question is then, how the Marshallian theorisation on the relationship between class and social citizenship (1950) contributes to understanding the existing 'social realities'. The social realities have many manifestations. One such manifestation is globalised production of goods and services (Deininger et al., 2011; UNIDO, 2015). The question at this juncture is, even if the global production chain does not follow the original invisible hand ${ }^{1}$ rule, what are its implications for Marshallian social citizenship? 
In the globalised economy, the original invisible hand rule is not followed. The value chains of production have crossed national boundaries. As a result of the crossing of national boundaries, the land acquisition ${ }^{2}$ drive has intensified over the past few decades to build factories and infrastructure. At a global level, according to The Land Matrix, recently acquired land deals in sixty-three low and middle-income countries have been estimated at forty-four million hectares (The Land Matrix, 2016). The World Bank identified a potential 445 million hectares, more than the area of India, for large-scale land investments (Deininger et al., 2011). Swift and enormous land acquisitions have led to many conflicts in India (Pellissery and Dey Biswas, 2012), and in the Global North-South (Bunkus and Theesfeld, 2019; Borras and Franco, 2012). These conflicts can be problematised as an inability to understand the plural values of land when realising property rights as a part of broader social citizenship rights. The dominant straitjacket monorational property rights discourse heavily relies on monetary price-based valuation, and therefore ignores the fact that land has plural values (Davy, 2012). In this context, the idea of absolute ownership and control (via exclusion of others) ignores the different ways in which plural values shape ideas of social citizenship. The unanswered questions are, (1) does monetary price truly represent the value of land, (2) is absolute ownership and control at the core of property rights, and (3) how does theory and empirical evidence of plural values shape ideas of social citizenship? Against this background, the article has considered two land expropriation case study areas in India, Salbani and Singur within the state of West Bengal, as a source of empirical data. The cases are not used for any comparison but rather to produce a theoretical generationalisation.

The article is divided into four sections. Following the introduction, the second section describes the theoretical foundations of the study and the methodology applied. The third section presents the empirical data and the fourth section connects the empirical evidence with Marshallian theorisation (1950) of social citizenship.

\section{Theoretical foundations}

Modern economics was inaugurated with a paradox popularly known as the paradox of value or the diamond-water paradox. Adam Smith discussed this on two occasions. For reasons unknown, one of the discussions (the popular paradox; Smith, 1776/1982, 44-45) has received excessive attention and the second discussion has been forgotten. The paradox is used to explain the preference between pleasure and pain. In the second case, the 'paradox' further includes factors such as 'colour, form, variety or rarity, and imitation'. The second example also discusses three determinants of price: '1st, the demand or need ...2ndly, the abundance or scarcity ... riches or poverty of those who demand' (Smith 1763/1896: 176-177). Yet in the next chapter of the same book, Smith accepted that value is represented by price (Smith, 1763/1896: 182-190). With this, Smith arguably implanted the first example of the everyday confusion of equating value and price (Dey Biswas, forthcoming).

Looking at the 'popular' diamond-water paradox (Smith, 1776/1982: 44-45), Davy (2012) concluded that age-old theories of value failed because they ignored that land has plural values and that values are socially constructed. The plurality can be summarised as the value of land as commodity or exchange value of land, territory or territorial value of land, capability or use value of land and ecology or existential 
value of land (p. 91). Land values can be accurately understood when looked at through the grid-box of the commodity, capability, territory and environmental values of land (Davy, 2012: 25-26). The value of land as commodity or exchange value of land is based on neoclassical economics, i.e. the equilibrium function of demand and supply (p. 97-101). The demand and supply inversely but simultaneously influence each other. Given that other factors are constant, with a rise in demand with a fixed supply the price will increase. On the other hand, when there is a fixed demand, the increased supply will decrease price. The territorial values include use and exchange values; social construction makes territorial values different from values as commodities (Davy, 2012: 116). The right to exclude (others) is one of the most important features of the territorial value of land (p. 114-117). The territorial value of land also depends on the degree of commodification possible for the land in question. Davy has also indicated that the territorial values and borders include not only legal rights but also political economy, geography, planning, sociology, environmental considerations, power and control via social inclusion and exclusion (Yang, 2018). The continuum of land rights, ranging from informal to formal, 'implies that more and better rights mean more spatial power' (Davy, 2012: 120, 124). Different plots of land might, therefore, command different territorial values since different spatial/territorial power ensures different rights, security and responsibility over resources/land.

Existence values or ecological values are also a social construction and a shared property of the human species (Davy, 2012: 135- 6). It is an ecological land rent and value that exist irrespective of how human society uses a piece of land (p. 131). The use value of land or value of land as capability is a synthesis of utilitarianism and the capabilities approach. The use value of land represents the utility of land, current and future use (p. 102); also 'land possesses a wide variety of capabilities to satisfy human needs' (p. 103). The value of land as capability or the use value of land depends on the quality of land, services and facilities available on a plot and accessible to a parcel of land. Use values are also influenced by the surrounding land and their use. Local networks, social recognition, social trust, knowledge of ecology, social economic conditions and one's relative position with the ecosystem are other important elements within the social construction of values of land as capability. Nussbaum ('Item 10') has contributed to developing a bridge between the use value and capabilities approach. Land use nourishes central capabilities of individuals, which is more than utilitarian theories of land will claim (Davy, 2012: 112; Nussbaum, 2006: 78).

When applied to land values during expropriation, neither the landowners/ stakeholders nor the expropriator will receive justice if the plural values of land are ignored. The plural values strike a balance between the burden and benefit derived from a set of policy actions. The demand of any science is to be explicit: therefore, the plural values of land have to be as explicit as the market-determined monetary price (Alexander and Penalver, 2012; Davy, 2012: 91). The dominant theories of value heavily rely on costbenefit analysis, cost of avoidance, indirectly measuring wages while considering how external factors influence life and living, and direct measurement of property values (Evans, 2004). ${ }^{3}$ The Lincoln Institute of Land Policy (2016) proposes that the value of the land is a function of the scarcity and supply of land at a specific location. Even though there is an increased importance of sustainability, ecological concerns, and social responsibility, the political economy of our time makes valuation an art, estimation, or projection (Royal Institution of Chartered Surveyors, 2008: 17). 
Within this brief review of theories of value and price ${ }^{4}$, there are a number of things to remember. Firstly, there is an obsession with equating monetary price with value (including but not restricted to land). Secondly, science demands explicitness: therefore, there is a tendency towards numbers agreed via quantification. Thirdly, the disconnected monorational value of land neither provides justice to the expropriator nor to those from whom it is expropriated. Marshall (1950: 68) believed, 'Social rights in their modern form imply an invasion of contract by status, the subordination of market price to social justice, the replacement of the free bargain by the declaration of rights. But are these principles quite foreign to the practice of the market today, or are they there already, entrenched within the contract system itself? I think it is clear that they are.' If values are represented in terms of monetary price, then how do theory and empirical evidence of plural values shape the ideas of social citizenship?

Contrary to the classical noble view, where slaves and women did not have any rights (Aristotle Politics: Barnes, 1991: 1253a11), one of the dominant contemporary ideas of citizenship called 'social citizenship', was developed by T. H. Marshall (1950). Marshall (1950) explored whether we could make every member of the society a gentleman and at the same time not equal. The use of the word gentleman should be reread as civilised (1950: 7), or in other words living in a 'modicum' of economic welfare and security (p.11). That process will disconnect economic monetary price from the labour produced and there should be an element of social security within the very structure of the wage system (p. 23). Marshall divided the idea of citizenship into three elements, civil, political and social, and at the same time accepted that such divisions are overlapping (p. 14), and are based on historical development rather than inherent logic (p. 10). The civil element includes rights that are necessary for 'individual freedom-liberty of the person, freedom of speech, thought and faith, the right to own property and to conclude valid contracts, and the right to justice' (p. 19). The political element entails ' ... the right to participate in the exercise of political power' (p. 11). The social element is defined by '... the right to a modicum of economic welfare and security to the right to share to the full in the social heritage and to live the life of a civilised being' (p. 11).

There are convergences and divergences of the Marshallian theory of social citizenship (1950) and Davy's plural values of land (Davy, 2012), but, to the best of my knowledge, never before has an attempt been made to evaluate whether valuation of land has any implication for the realisation of social citizenship rights. As discussed earlier, the existing theories of value have an obsession/tendency to measure the value of land in terms of monetary price. On the other hand, the non-monetary value or worthiness of the individual is one of the pillars of social citizenship rights. This pillar is built by subordinating market price to social justice (Marshall, 1950: 68). As theoretically grounded as these two theories may be, it is always better to put them through empirical investigation. The closer the gap between the established theories and social realities, the better the chance that these theories will explain the functioning of human society. Only then will social science be in the position to design tools for social improvement.

The article employs exploratory article design to understand plural values of land within the overarching theoretical understanding and assesses social realities connected with the idea of social citizenship. This empirical investigation takes two extreme or deviant cases, following embedded multiple-case study designs, which are closely 
defined or similar, as examples which may develop a theoretical generalisation (Yin, 1984: 44, 21; Flyvbjerg, 2006). Therefore, the rationale for choosing these two particular case studies are: (1) land acquisitions took place by applying the same Land Acquisition Act 1894; (2) the cases are located in a geographically and culturally similar context; and (3) completely opposite post-land-acquisition scenarios were produced after the application of the same law by the state of West Bengal, India. This selection of case studies allows us to exclude all other factors in order to focus on and explore different ways in which social citizenship via land can be understood by considering plural values of land. In the first instance, an organised and violent protest in Singur, West Bengal, India, ensured that Indian multinational conglomerate TATA could not use a newly-built car factory on state-acquired land. The severe resistance from the local population ensured the defeat of a Communist Party-led democratically elected coalition government in the next provincial election (West Bengal, India), after thirty-four years in power (Nielsen, 2018). This case was contrasted with the less-studied land acquisition case of Salbani, West Bengal, India, where land was expropriated for JSW Steel. Part of OP Jindal Group was given mostly 'fallow' land of 4860 acres to build a factory (Mathur, 2013: 162). The legislative head of the provincial government inaugurated the commencement for the construction of a 2.4 million-ton cement unit. Jindal promised to build a paint factory and a power producing plant on the acquired land in the following years and later inaugurated a cement factory in January 2018 (The Statesman, 2018). The JSW project has so far not faced severe opposition from those who are affected by this land acquisition.

\section{Empirical evidence}

The empirical data are a product of a seven month-long on-site residence and qualitative data collection in the above two case study areas via observations, sixty in-depth, one to two hours-long interviews, six focused group discussions with community members who were directly or indirectly affected by expropriation, local and regional politicians and representatives of industry. The transcript data were categorically indexed and thematically analysed (Mason, 2002).

The plural values of land encompass commodity, territory, capability and ecological values of land (Davy, 2012: 91). The participants in this study, located in Salbani and Singur in West Bengal, India, more easily described the value of land in terms of commodity and capabilities rather than the territorial and ecological values of land. The value of land as a commodity was defined as land which can be bought, sold or monetised and is subject to market speculation. The 'market' is a curious concept. While most of the participants of the study used the word, almost none of them could describe what really it is. As if the market is nameless, faceless and formless but nevertheless dictates the value of land as if with divine pre-ordinance. During the empirical investigation, irrespective of educational qualifications, from the secretariat of land records at the state-level to ordinary farmers, when asked about the actors in the market, all gave the same answers. Almost unanimously, the participants described the market actors as 'you and me'. Within the purview of 'us', those who have more money and power are the 'masters of the universe' (Moore, 2009). The neoclassical 'supply and demand' theory was described irrespective of educational background and gender. According to the participants of the study, these 'masters of the universe' are heavily involved with speculative land deals. The wealth of the bidders is pushing the value of 
land higher in terms of monetary price (Smith, 1763/1896: 176-177). Given the average 1,413 INR $^{5}$ monthly surplus available to the rural Indian home (NABARD, 2018), if not now, then soon, the speculation-led value of land in terms of monetary price will go beyond what the majority of rural households can afford. At the same time, the distribution of ownership and control over land arguably indicates that those who have less surplus income might want to have more access to land but cannot afford to do so (Basu et al., 2016).

According to the participants of the study, these speculative land deals help to hide un-taxed income. The speculative value of land as a commodity is often inflated by individuals with non-farm backgrounds, local or immediate outsiders who utilise insider information gained via political connections. Such speculative land deals via local muscleman-brokers in the Indian context has not gone unnoticed (Sud, 2014), but when seen as disenfranchised of the social 'modicum' via land then another picture emerges. The economic return from land, crops for farmers and business/real-estate opportunities, determine the value of land as commodity or the exchange value of land. ${ }^{6}$ At the same time, agriculture is becoming unprofitable and unpredictable (Mitra and Sarkar, 2003; Anderson, 2010: 3011), and therefore speculation with future non-agricultural perspectives in mind is becoming a dominant tendency. Conventional economic theories would consider the value of land as an investment for production in case of manufacturing but, according to the participants of the study, the same principle is not applied in the case of agricultural production. As agriculture becomes unprofitable all over the world, if land values are included in the cost of production then agriculture becomes arguably more unprofitable. The unprofitability and unpredictability have forced farmers towards secondary and tertiary employment to try to balance the loss of welfare benefit that could have been achieved via land (Nielsen, 2018). In this process, the subordination of market price to social justice remains partially a distant dream (Marshall, 1950: 68).

The economic and non-economic returns from the land often provide social security, including but not restricted to mortgages. This social security is also the foundation of Marshallian idea of citizenship (1950: 56, 83). Because of the inflation effect, the value of money decreases over time whereas land tends to retain its value. It can be used in the production process, such as via agriculture but the land remains 'unspent' as compared with the case of money or typical means of production. Therefore, the boundary between land value as commodity and capabilities realised via social security is often fuzzy. In the absence of comprehensive social security arrangements by the state, a reasonably just monetary only compensation demands that the land value is estimated by considering what it might command in the market in terms of monetary price in the future (i.e. in twenty or forty years from today). This is not easy for any individual or institution to pay outright. Ms Tanushree from Salbani elaborated how land affects the welfare outcome, providing social security at various stages of life.

'Just what I told you. From our land, my father and grandfather met their livelihood. From the land itself, our house is built. So many houses were there before, but whatever you can see now are being built from farming. Sons' marriage or the daughter's marriage (all) expenses were met through farming. We sold some (land), we produced crops in the rest of it, depending on the needs of the time.' 
In an absolutist sense, the right to property is different from any other right. The right to property includes the right to exclude others, which is the foundation of modern private property and the territorial value of land (Davy, 2012: 114-7). According to this doctrine, this is inviolable or sine qua non (Alexander and Penalver, 2012). This empirical case study found that the 'exclusion' phenomena are not so absolute. The exclusion is enforced to protect the returns from the land (for example, crops) but not the empty physical space. The cows roam when there are no crops in the field; people walk through another person's plot to reach a third person's house; children play; and travelling hawkers sell things for a few minutes without explicitly asking for permission from the owners. Mr Abir, a resident of Salbani, described how this system works.

'This is self-regulation. Yes. I can let my cows roam and I observe them that they are roaming on an empty plot. I monitor where they are going and what they are doing. I have to make sure that the cows are not going to some plot where there are crops. Once the grasses are finished in the area, I go to one plot and then move them to another plot.'

In exchange, the owners of the plots receive cow dung, good organic manure, goodwill in the community and reciprocal access to another house via someone else's plot. There are invisible boundaries created through existing informal practices (Davy, 2012; Yang, 2018), which protect the crops from grazing animals or control the behaviour of animals and people alike. In contrast to urban Indian practices, in rural areas an earthen ridge (not more than four inches tall in most cases) or trees indicate the boundaries. Physical walls around a plot are counterproductive because, if walls are built, no one will have access to agricultural land. Violation of such informal social practices, including but not restricted to identity-based norms (such as Indian caste systems) are dealt with by immediate prohibition or via informal social gatherings or informal courts (also called Salishi/Khap Panchayat; Dhar, 2014). These social gatherings are infamous for enforcing decisions which violate the constitution, laws and human rights, but at the same time they enforce egalitarian 'not so restricted/ exclusionary' land use.

The capabilities approach challenged our obsession with 'development ends' and instead asked us to reflect on the question, 'how can we achieve something that we want to achieve?' Davy (2012) applied the same principle to land values in line with Nussbaum (2006: 77). Nevertheless, this alone does not represent the plural values of land. The land provides the opportunities for an adequate and satisfying means of livelihood, it is the source of food grains, it establishes social identities, develops social bonds, informal social security, meets social responsibilities, is a source of prestige and social recognition, and a means of planning for the future. Land ensures a means of livelihood across generations and often acts as a trouble-shooter (intuitively as social security). In recent times, according to the participants of the study, the state (of West Bengal) has played a significant role in bringing certain improvements in agriculture with irrigation water and a higher budget for the local government. Years of a direct relationship with land make the non-financial value of land more important than the monetary return earned from the product. This is true even when the land provides just a minimum return to live on. It is because the monetary price of agricultural commodities commands less than the other necessities of life. The dominant political rhetoric is: 'Those who are devoted to land, will never give up their land. The land is soil, the soil is mother, and we do not sell our mother.' As politically charged as it may sound, in the absence of social security arrangements and 
employment opportunities or stability in life, this rhetoric recognises the welfare contribution of land. On the other hand, to the formally employed participants of the study, the land is less important for meeting livelihood requirements. It generates less sentimental value, less emotional attachment, and is not part of future planning.

The ecological or existential values of the land are the shared destiny of the human species and planet earth. Whether we are considering the sun, the rains, the air, the greens and entire ecological footprints of any piece of land, whether desert-like or a fertile plot next to the river Ganges, ecological values are present. During this empirical investigation, only a few participants of the study discussed the ecological value of land, and only when pushed. According to the participants of the study, the ecological values are secondary to immediate livelihood requirements. The participants of the group discussion held in Singur indicated how the environmental relationship plays a role in their lives.

\footnotetext{
'Mr Amit: During their life struggle, people are not thinking about such issues. First thing is to meet livelihood requirements, feed the family, take care of other needs, and the environment comes later. If something happens, (it) will happen later.

Ms Malabika: But we should protect our environment otherwise the future will be gloomy. Mr Amit: It is more like, we will live well. Whatever comes later will be dealt with later. For example, when we bought a piece of land in our family, we wanted to create a garden because we wanted to have shade, this is for the environment. But our prime importance is meeting livelihood requirements. We need a good education for our children, we need good health clinics in nearby areas.'
}

Only a few have accepted how they are indebted to the ecological values of land. They suspect that a growing population will force the clearance of more forests in the near future. Nevertheless, a few demanded that the state should ensure that newly built factories do not harm the local environment, and should prohibit too much chemical fertiliser in farming, polluted water and air. Marshall (1950: 61) was concerned about the 'physical environment', which arguably includes ecological environments, and directed those responsible for town planning to take care of the preservation of this valuable condition of social citizenship. The qualitative variation among various classes (in Marshallian sense) who are differently affected by environmental issues, considering that the well-off section of the population can afford water and water purifiers, should be tested against the demands of social justice. The contradictory disbelief in wellestablished environmental concerns compels me to ask which value (commodity, territory or capability) takes precedence in terms of the realisation of ecological values of land. The answer to this question, in my analysis, is neither provided by the theory of plural values (Davy, 2012) nor the theory of social citizenship (Marshall, 1950).

The plural values of land is a conceptual idea: therefore, it is hardly possible for individuals to articulate this with academic rigour. As a result, only a small number of participants have managed to describe plural values or came near to it. Mr Sourav, a resident of the Salbani area, indicated the difficulties in comprehending humans, as we are engaged with multiple tasks in our life which are not rational.

'Human beings are rational, and they have to analyse their own activity. There are multiple tasks in our life which are not rational. We mostly consider to the well-being of our life. There are again many factors which define wellbeing... It was just an example. The priorities of humans 
change and those priorities of humans decide their wellbeing. And the land value of a place also changes from place to place depending upon multiple factors. Yes, many aspects are considered but among them all, humans try to optimize. There are certain parameters which are very difficult to define.'

As priorities change, depending on location, land use and requirements of life, we take into consideration multiple factors. We try to find an optimum solution by considering all factors when some of the factors are difficult to even articulate. If there is an internal, simple or innate mechanism which helps us to determine or rank plural value, it is not yet fully understood. There are different ways to value land; in terms of agricultural production for the farmer, market speculation for land deal brokers, and investment for a factory owner, to give a few examples. These constitute the different ways in which plural values shape ideas of social citizenship.

\section{Discussion and conclusion}

The empirical evidence collected from the two land acquisition cases in West Bengal, India, indicates the existence of plural values of land and the different ways in which plural values shape the idea of social citizenship. Plural values of land include the value of land as a commodity, which the participants of the study in the first instance described in terms of monetary price. Upon further enquiry, the tendency to equate the value of land to monetary price has been seriously challenged by the participants of the study. The less talked about non-monetary value of land is one of the social realities that go beyond the established social security considerations. Yet, the value of land and value presented in terms of monetary price are defined and redefined by potential actors as per the realisation of social citizenship rights in a given society. The question is, what is the core demand of social citizenship rights that is influenced here? The core demand is the subordination of market price to social justice (Marshall, 1950: 68). Speculative or otherwise, the monetary price-based valuation of land and falling returns from agricultural production, arguably give market price superiority to the principles of social justice envisioned by the Marshallian theory of citizenship. In doing so, we are forced to make two conclusions at this juncture. The existing social reality reinforces the subordination of social justice to market price and the value of land is not restricted to the monorational monetary pricebased valuation mechanism only. The empirical evidence collected in India suggests the latter to be true. Whether or not the existing Indian or global political economy accepts this or not will be another question.

The plural values of land also question the idea of the exclusion-based monorational property rights doctrine in terms of its scope and limits. It is almost impossible to forbid others to benefit from land value as capability or use value of land, land value as ecology or existential values of the land. Is it possible to completely block others from enjoying the sun and the heat falling on my land, or the air available on my land? Sceptics will indicate how skyscrapers block the sun and air-conditioners and air purifiers create exclusionary zones for restricted groups of people. Even though there are a few black swans (air-conditioners/air purifiers), or perhaps grey to disprove that every swan is white (exclusion is impossible), plural values can be, hypothetically and to some extent in practice, exclusionary. ${ }^{7}$ The absolutist exclusionary based property value is questioned with the same plural values theory, i.e. other than in a few cases, it is difficult for plural 
values to be exclusionary. Yet, even a less-exclusionary property rights arrangement does not welcome a factory owner to establish its production unit on a piece of land without broader agreements with the owners and stakeholders. The empirical evidence indicates that the absolutist and contemporary legal exclusionary views are not universal. The exclusion is maintained on the fruits of the labour and not necessarily the physical space. The absence of a broad social security arrangement (and informal social protection from known people and the neighbourhood), very vital to the foundation of Marshallian citizenship rights, produces insecurity about the future. As a result, the subordination of market price to social justice in the Marshallian sense becomes unrealistic. When this core demand of social citizenship is affected, the overwhelming evidence of the climate change effect becomes secondary to tomorrow's survival needs (such as food and clothes).

With all the known scope and limits of the Marshallian theorisation of social citizenship, this empirical investigation demonstrates why there is a need to rediscover the 'social' in the property values of land. If global (plural) social citizenship rights (Marshall 1950: 59; Davy et al., 2013) are following plural paths, then the value of the land should take account of the social realities, improvement over time, and should aspire to further fulfilment of social citizenship rights. The 'social' in property values in land, therefore, is highly shaped by the existing social realities described earlier with empirical evidence. If social citizenship implies at least a minimal right to enjoy plural values of land, then no theory should neglect 'plural values' to understand the social reality. Unless social realities are rediscovered in the ideals and practice of Marshallian social citizenship - including but not restricted to the very plural understanding of the value of land that shapes realisation of social citizenship - neither the landowners/stakeholders nor the expropriators will receive justice. The absence of this understanding will continue to trigger more conflicts related to the expropriation of land.

\section{Acknowledgements}

I want to thank the anonymous reviewers and the editors for their constructive feedback. Also, I want to acknowledge fruitful discussions on the core themes of the article with Benjamin Davy, Franziska Seilker, Ivar Lødemel, M. Mercedes Stickler, Michael Kolocek, Paramita Roy, Rachelle Alterman, Sony Pellissery, Thomas Hartmann and Vandana Sharma. Jan Russell (jan@kabarmedia.com) has kindly copy edited this article. All remaining errors are mine.

\section{Notes}

1 The 'invisible hand' originally meant the home-bias of the merchants and benevolence of the kings/feudal lords (Smith, 1759/1853: 264-265; Smith, 1776/1982: 445-456).

2 Throughout this study, land acquisition and expropriation of land have been used interchangeably.

3 The professional valuation agrees on the five principle methods of valuation. They are; (a) the market approach or the comparative method, (b) the income approach or investment method, (c) the residual approach or development method, (d) the profit approach, and (e) the cost approach or contractor's method (Shapiro et al., 2012: 12-15). On the other hand, a professional valuation organisation such as The 
Royal Institution of Chartered Surveyors (Royal Institution of Chartered Surveyors, 2012) proposes three categories, namely (a) cost approach, (b) income approach, and (c) market approach.

4 This can be explored further at Dey Biswas (forthcoming).

5 At one Euro $=77.86$ Indian Rupees (INR) exchange rate as on 28-05-2019, 1,413 INR is equal to 18.14 Euro.

6 This mechanism is well established in real-estate literature as Revenue Capitalisation Method (Davy, 2012: 100).

7 For the idea of 'falsification', please see Popper (1959/2005).

\section{References}

Alexander, G. S. and Penalver, E. M. (2012) An Introduction to Property Theory, Cambridge: Cambridge University Press.

Anderson, K. (2010) 'Globalization's effects on world agricultural trade, 1960-2050', Philosophical Transactions of the Royal Society B Biological Sciences, 365, 1554, 3007-21.

Barnes, J. (1991) The Complete Works of Aristotle - The Revised Oxford Translation, Princeton, N.J: Princeton University Press.

Basu, K., Dey Biswas, S., Harish, P., Dhar, S. and Lahiri, M. (2016) Is multiparty Coalition Government Better For the Protection of Socially Backward Classes in India?, 2016/109. Helsinki: UNU-WIDER.

Borras, S. and Franco, J. (2012) 'Global land grabbing and trajectories of agrarian change: a preliminary analysis', Journal of Agrarian Change, 12, 1, 34-59.

Bunkus, R. and Theesfeld, I. (2019) 'Land grabbing in Europe? Socio-cultural externalities of large-scale land acquisitions in East Germany', Land, 7, 3, 98; https://doi.org/10.3390/land7030098.

Davy, B, Davy, U. and Leisering, L. (2013) 'The global, the social and rights: new perspectives on social citizenship', International Journal of Social Welfare, 22, S1-14.

Davy, B. (2012) Land Policy: Planning and the Spatial Consequences of Property, Farnham: Ashgate.

Deininger, K., Byerlee, D., Lindsay, J., Norton, A., Selod, H. and Stickler, M. (2011) Rising Global Interest in Farmland: Can it Yield Sustainable and Equitable Benefits? Agriculture and Rural Development, Washington, DC: World Bank, http://documents.worldbank.org/curated/en/998581 468184149953/Rising-global-interest-in-farmland-can-it-yield-sustainable-and-equitable-benefits [accessed 29.08.2019].

Dey Biswas, S. (forthcoming) Land Acquisition and Compensation in India: Mysteries of Valuation, NY: Palgrave Macmillan, doi: 10.1007/978-3-030-29481-6.

Dhar, S. (2014) 'West Bengal woman says gang-raped on orders of panchayat', Reuters, 23 January, https:// in.reuters.com/article/rape-panchayat-west-bengal-love/west-bengal-woman-says-gang-raped-onorders-of-panchayat-idINDEEAOMOAA20140123 [accessed 29.08.2019].

Evans, A. W. (2004) Economics and Land Use Planning, Oxford: Blackwell.

Flyvbjerg, B. (2006) 'Five misunderstandings about case-study research', Qualitative Inquiry, 12, 2, 219-45.

Lincoln Institute (2016) Land and Property Values in the U.S. Tech. rep., Lincoln Institute of Land Policy, http://datatoolkits.lincolninst.edu/subcenters/land-values/ [accessed 29.08.2019].

Marshall, T. H. (1950) Citizenship and Social Class: And Other Essays, Cambridge: Cambridge University Press.

Mason, J. (2002) Qualitative Researching, London: Sage.

Mathur, H. M. (2013) Displacement and Resettlement in India: The Human Cost of Development, London: Routledge.

Mitra, S. and Sarkar, A. (2003) 'Relative profitability from production and trade: a study of selected potato markets in West Bengal', Economic and Political Weekly, 38, 44, 4694-9.

Moore, S. (2009) 'Masters of the universe', Financial Times, 27 November, https://www.ft.com/content/ 68d6ad0a-da21-11de-b2d5-00144feabdc0 [accessed 29.08.2019]. 
National Bank for Agriculture and Rural Development (NABARD) (2018) All India Rural Financial Inclusion Survey 2016-17 (NAFIS), https://www.nabard.org/auth/writereaddata/tender/1608180417NABARDRepo-16_Web_P.pdf [accessed 29.08.2019].

Nielsen, K. B. (2018) Land Dispossession and Everyday Politics in Rural Eastern India, London and NY: Anthem Press.

Nussbaum, M. C. (2006) Frontiers of Justice: Disability, Nationality, Species Membership. The Tanner Lectures on Human Values, Cambridge, Massachusetts: Belknap Press.

Pellissery, S. and Dey Biswas, S. (2012) 'Emerging property regimes in India: what it holds for the future of socio-economic rights?', Working Paper 234, Institute of Rural Management Anand, https:// www.irma.ac.in/ipublications/publicationdetail.php?cid=2\&pid=1175 [accessed 29.08.2019].

Popper, K. (1959/2005) The Logic of Scientific Discovery, London and NY: Routledge Classics.

Royal Institution of Chartered Surveyors (2008) Valuation Standards. Tech. rep., Royal Institution of Chartered Surveyors, London.

Royal Institution of Chartered Surveyors (2012) RICS Valuation - Professional Standards; Global Edition, Royal Institution of Chartered Surveyors, London.

Shapiro, E., Mackmin, D. and Davies, K. (2012) Modern Methods of Valuation, 11th edn, Estates Gazette. Smith, A. (1759/1853) The Theory of Moral Sentiments; or, An Essay towards an Analysis of the Principles by which Men Naturally Judge Concerning the Conduct and Character, First of Their Neighbours, and Afterwards of Themselves, To which is added, A Dissertation on the Origins of Languages, New Edition, with a biographical and critical memoir of the author, by Dugald Stewart, London: Henry G. Bohn, https://oll.libertyfund.org/titles/2620 [accessed 29.08.2019].

Smith, A. (1763/1896) Lectures on Justice, Police, Revenue and Arms, delivered in the University of Glasgow: Reported by a Student in 1763 and edited with an introduction and notes, by Edwin Cannan, Oxford: Clarendon Press, http://oll.libertyfund.org/titles/2621 [accessed 29.08.2019].

Smith, A. (1776/1982) An Inquiry into the Nature and Causes of the Wealth of Nations, Indianapolis: LibertyClassics.

Sud, N. (2014) 'The men in the middle: a missing dimension in global land deals', The Journal of Peasant Studies, 41, 4, 593-612.

The Land Matrix (2016) 'The online public database on land deals, The Land Matrix, http:// www.landmatrix.org/en/ [accessed 29.08.2019].

The Statesman (2018) 'Mamata opens JSW unit at Salboni', The Statesman, https://www.thestatesman.com/ cities/mamata-opens-jsw-unit-salboni-1502565242.html [accessed 29.08.2019].

United Nations Industrial Development Organization (UNIDO) (2015) Global Value Chains and Development: UNIDO's Support towards Inclusive and Sustainable Industrial Development, https:// www.unido.org/sites/default/files/2016-03/GVC_REPORT_FINAL_0.PDF [accessed 29.08.2019].

Yang, Y. (2018) Land Use and Social Rights: A Boundary Perspective on the Urban Village in Contemporary China, Bodenpolitik, Bodenmanagement und kommunales Vermessungswesen, School of Spatial Planning, TU Dortmund University, http://dx.doi.org/10.17877/DE290R-19138 [accessed 29.08.2019].

Yates, R. (1787) Notes of the Secret Debates of the Federal Convention of 1787, Taken by the Late Hon. Robert Yates, Chief Justice of the State of New York, and One of the Delegates from That State to the Said Convention, http://avalon.law.yale.edu/18th_century/yates.asp [accessed 29.08.2019].

Yin, R. K. (1984) Case Study Research: Design and Methods, Beverly Hills, California: Sage Publications. 